\title{
Ethanol Affects the Absorption and Tissue Distribution of Orally Administered Antigens in Mice
}

\author{
Flávia Márcia Oliveira ${ }^{1 *}$, Leandro José Gusmão ${ }^{2}$, Valbert do Nascimento Cardoso ${ }^{3}$, Gilson \\ Andrade Ramaldes ${ }^{3}$, Valéria Ruiz-de-Souza ${ }^{4}$ and Cristiano Machado Gontijo ${ }^{4}$ \\ ${ }^{I}$ Departamento de Educação em Saúde; Universidade Federal de Sergipe; Lagarto - SE - Brasil. ${ }^{2}$ Campus da \\ Saúde; Centro Universitário do Leste de Minas Gerais; Ipatinga - MG - Brasil. ${ }^{3}$ Faculdade de Farmácia; \\ Universidade Federal de Minas Gerais; Belo Horizonte - MG - Brasil. ${ }^{4}$ Instituto de Ciências Biológicas; \\ Universidade Federal de Minas Gerais; Belo Horizonte - MG - Brasil
}

\begin{abstract}
The aim of this work was to evaluate the effects of ethanol on the adsorption and tissue distribution of orally administered antigens in mice. Results showed that ethanol reduced the level of anti-ovalbumin IgA antibodies in intestinal fluid for the mice treated orally with a palmitoyl-ovalbumin conjugate. Ethanol was administered intragastrically to mice at $5 \mathrm{~g} / \mathrm{kg}$ body weight for 14 days (chronic treatment), or $10 \mathrm{~g} / \mathrm{kg}$ body weight every $7^{\text {th }}$ day up to 14 days (acute treatment). Thereafter, ${ }^{99 m}$ technetium-labeled antigens were administered and lymphoid tissues were collected. Ethanol interfered with the transport of ovalbumin to the liver. Moreover, the transport of palmitoyl-ovalbumin to mesenteric lymph nodes was reduced $6 \mathrm{~h}$ after the antigen administration. In conclusion, there was a relationship between the suppression of ethanol-mediated specific local IgA responses and the decreased transport of palmitoyl-ovalbumin to mesenteric lymph nodes.
\end{abstract}

Key words: ethanol, absorption, biodistribution, technetium, immune response

\section{INTRODUCTION}

Orally administered antigens interact with gutassociated lymphoid tissue, which comprises of epithelial cells and intra-epithelial and lamina propria lymphocytes (Brandtzaeg 1985; McGhee et al. 1992). These antigens are drained into Peyer's patches and mesenteric lymph nodes (MLNs), or the liver. The most common consequence of the oral administration of antigens is the oral tolerance induction that comprises a state of systemic humoral and cellular responses suppression to fed antigens (Challacombe and Tomasi 1980; Titus and Chiller 1981). Moreover, antigens can activate the intestinal mucosal immune system, resulting in antigen-specific IgA production, or systemic immunization.

Several mechanisms that induce the suppression of antigen-specific immune responses in oral tolerance have been proposed, including clonal deletion, anergy, and dominant tolerance involving active immune suppression by CD4+ CD25+ Foxp3+ regulatory $\mathrm{T}$ cells (Tregs). This last mechanism is of particular relevance to the present study because it involves self-reactive, thymically derived, naturally occurring Tregs and inducible Tregs produced from the antigen-specific naïve CD4+ CD25- Foxp3- $\mathrm{T}$ cells in peripheral areas under certain environmental conditions (Hori et al. 2003; Keir et al. 2008; Curotto de Laifaille and Lafaille 2009; Zhou et al. 2009).

*Author for correspondence: fmo.75@hotmail.com 
Thus, several factors such as the route of antigen uptake determine the type and magnitude of the ensuing immune response against orally administered antigens (Emark et al. 1995; Matsunaga et al. 2001; Jonh et al. 2002). Antigens are taken up by either the $\mathrm{M}$ cells in Peyer's patches, or epithelial cells in the villi, and this uptake is dependent largely on the nature (i.e., particulate or soluble) and size of the antigen (Nakaoka et al. 1996; Tabata et al. 1996).

Factors that affect the integrity of the intestinal wall can alter the antigen absorption and tissue distribution, and consequently, immunological responses. For instance, ethanol can alter the morphology and physiology of the intestinal wall, promote serious damage to the gastric mucosa by destroying $10-50 \%$ of villi and enhance intestinal permeability (Andrade et al. 2006; Beck et al. 1996). A previous study had shown that palmitoyl-ovalbumin (palmitoyl-ova), not the naïve ova, was efficient in generating the humoral and cellular immunity (Oliveira et al. 2002). Palmitoyl-ova also stimulated the production of IgA antibodies (Oliveira et al. 2002). By contrast, the levels of $\operatorname{IgA}$ antibodies were lower in the intestinal fluid from ethanol-treated mice (Gusmão et al. 2004); however, systemic immunization and oral tolerance against palmitoyl-ova and ova, respectively, were not affected by ethanol (Gusmão et al. 2004). This study evaluated the effects of ethanol on the absorption and tissue distribution of ova and palmitoyl-ova after oral administration.

\section{MATERIALS AND METHODS}

\section{Animals}

Male and female B6D2F1 mice (age, 7-9 weeks; $\mathrm{n}$ $=12$ per group), alternatively known as (C57B1/6xDBA/2) F1 hybrids, were obtained from the breeding unit at the Federal University of Minas Gerais (UFMG - Belo Horizonte, Brazil).
Studies were conducted in accordance with the Brazilian Society for Neuroscience and Behaviour Guidelines for Animal Experimentation.

\section{Antigens}

Chicken egg albumin (ova, grade V) was purchased from the Sigma Chemicals Co. (St. Louis, MO, USA). Lipid-ova conjugates (i.e., palmitoyl-ova) were prepared as described previously (Oliveira et al. 1998). In brief, $1.0 \mathrm{~g}$ of the N-hydroxysuccinamide ester of palmitate (Sigma) was dissolved in $100 \mathrm{~mL}$ of absolute ethanol at $55^{\circ} \mathrm{C}$. This mixture was then combined with $800 \mathrm{~mL}$ of phosphate-buffered saline containing $4.0 \mathrm{~g}$ ova and $0.6 \%$ deoxycholate (wt/vol, Sigma) at $37^{\circ} \mathrm{C}$. After overnight incubation at room temperature, the mixture was centrifuged and the precipitate was collected. The precipitate was washed with $50 \mathrm{mM} \mathrm{NaHCO}$, and a suspension was prepared. After freezing the suspension in the liquid nitrogen, the conjugate was lyophilized.

\section{Ethanol treatment}

Ethanol was administered intragastrically to mice at $5 \mathrm{~g} / \mathrm{kg}$ body weight for 14 days (chronic treatment), or $10 \mathrm{~g} / \mathrm{kg}$ body weight every $7^{\text {th }}$ day up to 14 days (acute treatment).

\section{Labeling antigens with technetium $\left({ }^{99 \mathrm{~m}} \mathrm{Tc}\right)$}

Ova and palmitoyl-ova were incubated with $10 \mu \mathrm{l}$ $\mathrm{SnCl}_{2}\left(2 \mathrm{mg} / \mathrm{ml} \mathrm{SnCl}_{2}\right.$ in $\left.0.25 \mathrm{M} \mathrm{HCl}\right), 10 \mu \mathrm{l}$ $\mathrm{NaBH}_{4}(2 \mathrm{mg} / \mathrm{ml} \mathrm{NaBH} 4$ in $0.1 \mathrm{M} \mathrm{NaOH})$, and 4 $\mathrm{MBq}$ of ${ }^{99 \mathrm{~m}} \mathrm{Tc}$ for $20 \mathrm{~min}$ at room temperature. Labeling efficiency, determined as described previously (Araújo et al. 2002), was $95 \% \pm 0.5$ (n $=50$ ). The antigenic integrity of ${ }^{99 \mathrm{~m}} \mathrm{Tc}$-labeled antigens was assessed by affinity chromatography and labeling did not affect the antigenic properties. The mixture was concentrated using a disposable microconcentrator to remove the unbound ${ }^{99 \mathrm{~m}} \mathrm{Tc}$ before use (Alves et al. 2005).

Table 1 - Ethanol treatment protocol.

\begin{tabular}{cccccccccccccccc}
\hline \multicolumn{11}{c}{ Ethanol treatment protocol } \\
\hline Day & 0 & 1 & 2 & 3 & 4 & 5 & 6 & 7 & 8 & 9 & 10 & 11 & 12 & 13 & 14 \\
Acute ethanol treatment g/kg body weight & 10 & - & - & - & - & - & - & 10 & - & - & - & - & - & - & 10 \\
Chronic ethanol treatment g/kg body weight & 5 & 5 & 5 & 5 & 5 & 5 & 5 & 5 & 5 & 5 & 5 & 5 & 5 & 5 & 5 \\
\hline
\end{tabular}

\section{Biodistribution of labeled antigens}

Aliquots containing $20 \mathrm{mg}$ of labeled antigens (20$\mathrm{mg}$ aliquots) were administered by gavage to mice.
The mice were sacrificed 1 and $6 \mathrm{~h}$ after antigen administration, bled, and internal organs such as the stomach, MLNs, spleen, liver, small and large 
intestines, and Peyer's patches were collected. The organs were washed briefly with saline, dried, and weighed. The small intestine was divided into three segments of equal length. Intestinal fluid was obtained after rinsing each segment with $1.0 \mathrm{ml}$ saline. Peyer's patches from each segment were removed and tested. Radioactivity was measured in different organs using an automatic scintillation apparatus (ANSR-Abbot, USA). To determine the rate of radioactive decay and to standardize the assay, the number of counts per minute was measured in the aliquots.

\section{Statistical analysis}

Differences between the ova $(\mathrm{n}=12)$ and palmitoyl-ova $(n=12)$ groups were evaluated by two-tailed unpaired Student's $t$-test. Statistics were performed using GraphPad Prism 5 software for Windows (San Diego, CA, USA). $p<0.05$ was considered statistically significant. Data are from at least three experiments, and results are expressed as mean \pm S.D.

\section{RESULTS AND DISCUSSION}

The acute and chronic administration of ethanol caused macro- and microscopic morphological changes in the intestine, which caused a reduction in villus height (data not shown).

To determine the effects of morphological changes induced by ethanol on the absorption and tissue distribution of orally administered antigens (ova and palmitoyl-ova), the presence of ${ }^{99 \mathrm{~m}} \mathrm{Tc}$-labeled antigens in Peyer's patches, MLNs, liver, spleen, and blood was analysed. Figure 2 shows the distribution of labeled antigens $1 \mathrm{~h}$ after administration. An acute dose of ethanol resulted in a significant increase in the level of palmitoylova in Peyer's patches $1 \mathrm{~h}$ after antigen administration. In addition, the level of ${ }^{99 \mathrm{~m}} \mathrm{Tc}$ labeled palmitoyl-ova increased in the liver of ethanol-treated mice; however, the level of ${ }^{99 \mathrm{~m}} \mathrm{Tc}$ labeled ova decreased in this organ. Ethanol did not affect antigen distribution in MLNs and blood.

Figure 2 also shows the absorption and tissue distribution of labeled antigens $6 \mathrm{~h}$ after administration. The levels of palmitoyl-ova increased in the spleen and blood. By contrast, ethanol reduced the level of palmitoyl-ova in MLNs. The absorption and distribution of ${ }^{99 \mathrm{~m}} \mathrm{Tc}$ labeled ova in untreated and ethanol-treated mice were comparable 1 and $6 \mathrm{~h}$ after, except that a lower level was observed in the liver after $1 \mathrm{~h}$. The absorption and distribution of ${ }^{99 \mathrm{~m}} \mathrm{Tc}$-labeled ova and palmitoyl-ova were similar in the mice treated with acute or chronic doses of ethanol (data not shown).

Mucosal tissues are constituted by physiological and immunological barriers that restrict the entry of the antigen into organisms. Even though the glycocalyx, mucins, secretory $\operatorname{IgA}$ antibodies, and junctional structures reduce the macromolecule intestinal transport, significant amounts of soluble and particulate antigens penetrate in lamina propria through paracellular pathway, enterocytes or M cells (Sun et al. 1997; Lennernãs 1998). The cellular events that modulate antigen uptake and processing appear to determine whether feeding of antigen induces the tolerance, or primes an immune response in the gastrointestinal tract (Mestecky et al. 1997; Gamvrellis et al. 2004).

Ethanol may also play a role in the uptake of antigens in the gut and in the immune responses triggered by orally administered antigens. An earlier study has demonstrated a decrease in the level of IgA antibodies against palmitoyl-ova in the intestinal fluid from ethanol-treated mice; however, systemic immunological events induced by orally administered antigens were not affected (Gusmão et al. 2004). In this study, ${ }^{99 \mathrm{~m}} \mathrm{Tc}$, a radionuclide widely used to label the drugs, peptides and antibodies was used for biodistribution studies (Jamar et al. 2002). Free ${ }^{99 \mathrm{~m}} \mathrm{Tc}$ accumulates largely in the thyroid and stomach wall (Argonne National Laboratory 2005).

The paracellular pathway is restricted to the transport of ions and anions. However, pathologies, or ethanol consumption increase the permeability of the intestinal wall due to the junctional barriers damage (Borrielo, 2001). The higher antigen levels observed in the liver and blood at 1 and $6 \mathrm{~h}$, respectively, illustrated an increase in the permeability to palmitoyl-ova in ethanol-treated mice. On the other hand, ethanol did not affect the absorption of ova and only the ova level in the liver was reduced at $1 \mathrm{~h}$. These showed that the antigen absorption in ethanoltreated mice was dependent on the nature of the molecule. In other words, the absorption of hydrophobic and particulate antigens was higher than that of soluble antigens.

The transport of macromolecules via enterocytes, or $\mathrm{M}$ cells was also influenced by their nature and size. For instance, soluble molecules are 
transported via enterocytes with a similar kinetics (Mayer et al. 1999). On the other hand, the transport of particulate antigens via enterocytes is limited because of their size; therefore, these antigens are mainly transported by $\mathrm{M}$ cells (Eldrige et al. 1991; Desai et al. 1996; Chen and Langer 1998; Matsunaga et al. 2001). In agreement with the previous observations, the uptake of palmitoyl-ova, a particulate and

$1 \mathrm{~h}$ after feeding:

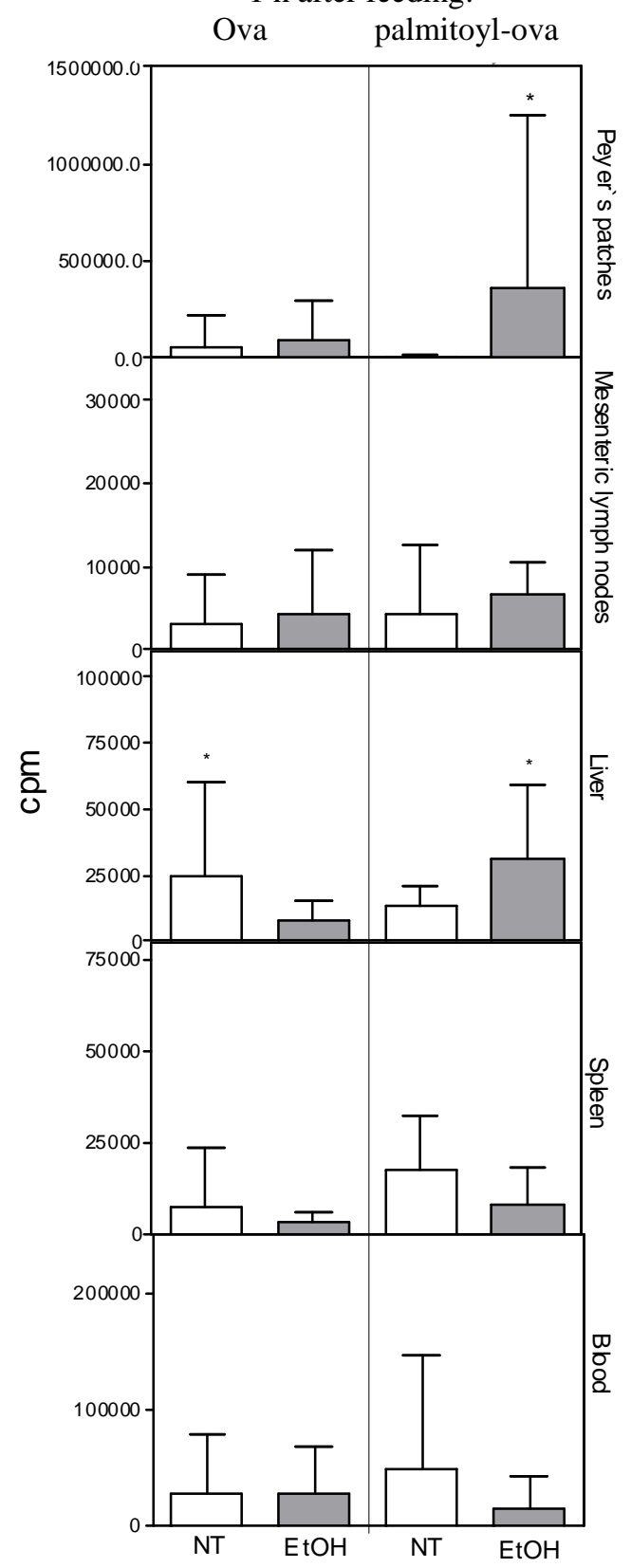

hydrophobic antigen, by Peyer's patches was higher than that of ova (Oliveira et al. 2002; Oliveira et al. 2007). However the uptake of palmitoyl-ova in ethanol-treated mice was higher after $1 \mathrm{~h}$, but not after $6 \mathrm{~h}$ after antigen administration. In other words, ethanol reduced the maintenance of palmitoyl-ova in the Peyer's patches.

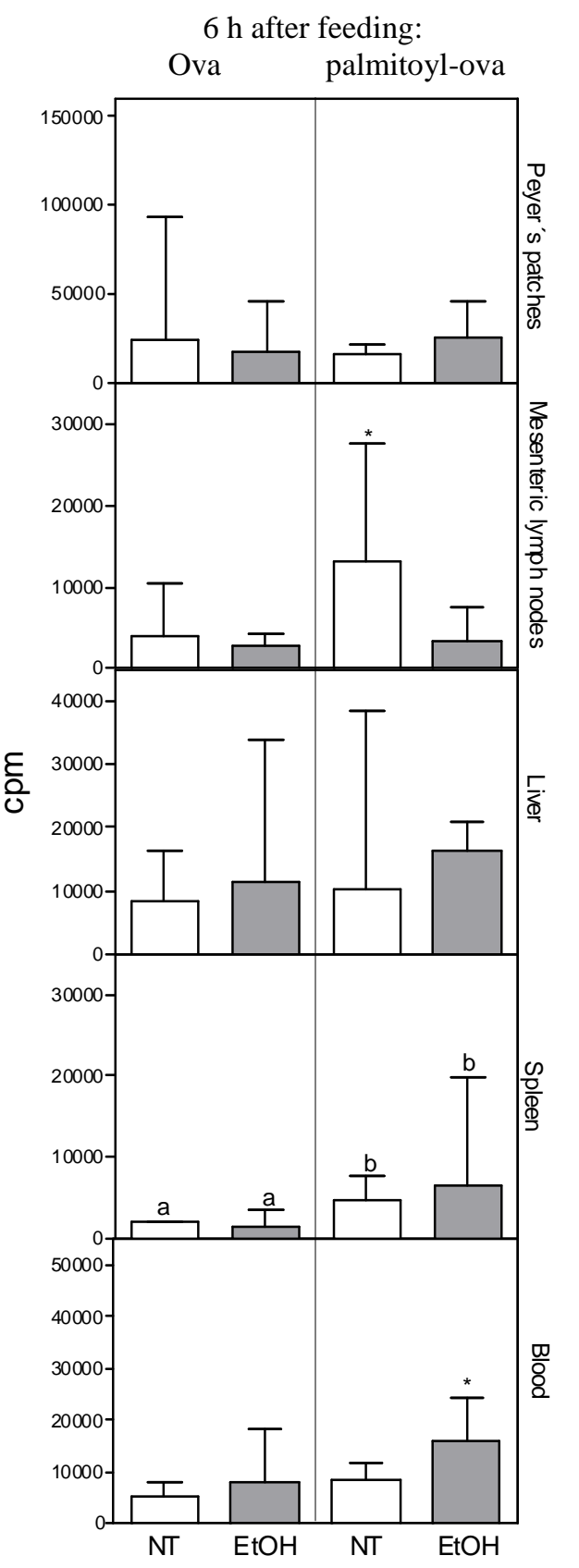

Figure 2 - Uptake of radiolabeled antigens in Peyer's patches, mesenteric lymph nodes, liver, spleen and blood. B6D2F1 mice received acute doses of ethanol $(\mathrm{EtOH} ; \mathrm{n}=12)$ or saline $(\mathrm{NT} ; \mathrm{n}$ $=12)$. Treated and untreated animals were fed ${ }^{99 \mathrm{~m}} \mathrm{Tc}$-labeled ova or ${ }^{99 \mathrm{~m}} \mathrm{Tc}$-labeled palmitoyl-ova, and organs were removed and weighed. $p(\mathrm{a} / \mathrm{b})<0.05$ or $p(*)<0.05$ represents a significant difference between groups. 
The most significant effect of ethanol administration on palmitoyl-ova distribution was a reduction in antigen levels in MLNs. Hydrophobic antigens such as palmitoyl-ova are drained by MLNs and subsequently delivered into the bloodstream (Reddy and Murthy 2002). Within MLNs, immune responses are triggered by the activation and differentiation of resident cells. In contrast to contradictory reports on the importance of Peyer's patches, MLNs play a crucial role in the induction of mucosal immunity and tolerance. For instance, studies have shown an inhibition of mucosal immunization induced by the particulate antigens in the absence of MLNs (Yamamoto et al. 2000; Alpan et al. 2001). In addition, CD47-/mice, which have significantly less CD11b+ CD172a+ dendritic cells within MLNs, showed a reduction in the enterotoxin-induced $\operatorname{IgA}$ immunity in the gut (Westlund et al. 2012). The heterogeneity of dendritic cells within MLNs may play different roles in the induction of oral tolerance and in driving the systemic immune responses after vaccination, or intestinal stimulation with Toll-like receptor ligands (Onodera et al. 2009; Milling et al. 2010). These results suggested that there was a relationship between the suppression of ethanol-mediated IgA responses and the decrease in palmitoyl-ova transport to MLNs. Future studies should investigate the effects of ethanol on the cellular signaling and activation after orally administered antigens.

In contrast to the effects of ethanol on mucosal immunity against the palmitoyl-ova, systemic immunity was not affected by the treatment. A previous study suggested that M cells, Peyer's patches, and MLNs might only be involved in local gut responses to particulate antigens and that other cells might be involved in systemic responses to orally administered antigens (Alpan et al. 2001). This was supported by the roles of the spleen (Barsante et al. 2001; Oliveira et al. 2002) and liver ( $\mathrm{Li}$ et al. 2004) in the development of systemic immunization, or tolerance to orally administered antigens. Thus, systemic immune responses remained unchanged because ethanol did not affect the levels of these antigens in these organs.

\section{CONCLUSION}

Results showed that ethanol caused morphological and physiological changes that modify the absorption and mucosal lymphoid tissue distribution of orally administered particulate antigens. Changes in antigen biodistribution might play a role in the suppression of intestine-specific antibody production.

\section{REFERENCES}

Alpan O, Rudomen G, Matzinger P. The role of dendritic cells, B cells, and $\mathrm{M}$ cells in gut-oriented immune responses. Immunol. 2001; 166: 4843-4852.

Alves AC, Gontijo CM, Oliveira MC, Diniz SOFD, Oliveira FM, Cardoso VN, Ramaldes GA. Biodistribution of free ${ }^{99 \mathrm{~m}} \mathrm{Tc}$-ovalbumin and ${ }^{99 \mathrm{~m}} \mathrm{Tc}$ ovalbumin encapsulated in liposomes. Braz Arch Biol Tech. 2005; 48: 235-241.

Andrade MC, Menezes JS, Cassali D, Martins-Filho AO, Cara DC, Faria AMC. Alcohol-induced gastritis prevents oral tolerance induction in mice. Clin Exp Immunol. 2006; 146(2):312-22.

Araújo JGVC, Toledo VPCP, Guimarães TMPD, Bernardo-Filho M, Simal CJR, Mota LG, Diniz SOF, Cardoso VN. Technetium ${ }^{99 \mathrm{~m}}$ labeling anti- amastigote polyclonal antibodies of Leishmania amazonensis. Nucl Med Biol. 2002; 29:405-411.

Argonne National Laboratory. Human Heath Fact Sheet. 2005. 2 p.

Barsante MM, Speziali E, Ficker SM, Assis FA, Vaz NM, Faria AMC. Splenectomy does not abrogate oral tolerance induction in mice. Scand J Immunol. 2001; 54: 106-110.

Beck IT, Morris GP, Buell MG. Ethanol-induced vascular permeability changes in the jenjunal mucosa of the dog. Gastroenterol. 1996; 90:1137-1145.

Boriello P. Bugs and the gut: breaking barriers to understanding gut. Gut. 2001; 48:503-507.

Brandtzaeg P. Research in gastrointestinal immunology. State of art. Scand J Gastroenterol. 1985; 20: 137156.

Challacombe SJ, Tomasi TB. Systemic tolerance and secretory immunity after oral immunization. J Exp Med 1980: 152: 1459-1472.

Chen H, Langer R. Oral particulate delivery: status and future trends. Adv Drug Deliv Rev. 1998; 34:339-350.

Curotto de Lafaille MA, Lafaille JJ. Natural and adaptative Foxp3 regulatory T cells: more the same or a division labor. Immunity. 2009; 30(5): 626-635.

Desai MP, Labhasetwar V, Amindon GL, Levy RJ. Gastrointestinal uptake of biodegradable microparticles: effect of particle size. Pharm Res. 1996; 13(12):1838-1845.

Eldrigde JH, Staas JK, Meulbroek JA, Tice TR, Gilley RM. Biodegradable microspheres as a vaccine delivery system. Mol Immunol. 1991; 28(3):287-294. 
Ermak TH, Doughertu EP, Bhagat HR, Kabok Z, Pappo J. Uptake and transport of copolymer biodegradable microsphere by rabbit Peyer's patch M cells. Cell Tissue Res. 1995; 279(2): 433-436.

Gamvrellis A, Leong D, Mottram P, Plebanski M. Vaccines that facilitate antigen entry into dendritic cells. Immunol Cell Biol. 2004; 82: 506-516.

Gusmão LJ, Barreto PL, Araújo TF, Costa NP, Costa SS, Gontijo CM, Oliveira FM. Efeitos da administração de etanol sobre fenômenos imunológicos desencadeados por via oral em camundongos. Doxa. 2004; 6(1): 21-27.

Hori S, Nomura T, Sakaguchi S. Control of regulatory $\mathrm{T}$ cell development by transcription factor Foxp3. Science. 2003: 299(5609): 1057-1061.

Jamar F, Houssiau FA, Devogelaer JP, Chapman PT, Haskard DO, Beaujean V, Beckers C, Manicourt DH, Peters AM. Scintigraphy using a technetium 99mlabelled anti-E-selectin Fab fragment in rheumatoid arthritis. Rheumatol. 2002; 41(1): 53-61.

Jonh M, Bridges EA, Miller AO, Calderwood SB, Ryan ET. Comparison of mucosal and systemic humoral immune responses after transcutaneous and oral immunization strategies. Vaccine. 2002; 20: 27202726.

Keir ME, Butte MJ, Freeman GJ, Sharpe AH. PD-1 and its ligands in tolerance and immunity. Annu Rev Immuno. 2008: 26: 677-704

Lennernãs H. Human intestinal permeability. J Pharm Sci. 1998; 87:403-410.

Li W, Chou ST, Wang C, Kuhr CS, Perkin JD. Role of the liver in peripheral tolerance induction through oral antigen feeding. Am J Transpl. 2004; 4:1574158.

Matsunaga Y, Wakatsuki Y, Tabata Y, Kawasaki H, Usui T, Yoshida M, et al. Oral immunization with size-purified microsphere beads as a vehicle selectively induces systemic tolerance and sensitization. Vaccine. 2001; 19:579-588.

Mayer LD, Reamer J, Bally MB. Intravenous pretreatment with empty $\mathrm{pH}$ gradient liposomes alters the pharmacokinetics and toxicity of doxorubicin through in vivo active drug encapsulation. J Pharm Sci. 1999; 88(1):96-102.

McGhee JR, Mestecky J, Dertzbaugh MT, Eldridge JH, Hirasawa $M$, Kiyono $H$. The mucosal immune system: from fundamental concepts to vaccine development. Vaccine. 1992; 10(2):75-78.

Mestecky J, Michalek SM, Moldoveanu Z, Russell MW. Routes of immunization and antigen delivery systems for optimal mucosal immune responses in humans. Behring Inst Mitt. 1997; 98:33-43.

Milling S, Yrlid U, Cerovic V, MacPherson G. Subsets of migrating intestinal dendritic cells. Immunol Rev. 2010. 234(1): 259-267.
Nakaoka R, Inoue Y, Tabata Y, Ikada Y. Size effect on the antibody production induced by biodegradable microspheres containing antigen. Vaccine. 1996; 14(13):1251-1256.

Oliveira FM, Santos EM, Alves AC, Campana-Pereira MA, Ramaldes GA, Cardoso VN, Ruiz-de-Souza V, Gontijo CM. Digestion, Absorption and Tissue Distribution of Ovalbumin and Palmitoyl-ovalbumin: Impact on Immune Responses Triggered by Orally Administered Antigens. Scand J Immunol. 2007; 65(2):139-147.

Oliveira FM, Santos EM, Mota-Santos TA, Ruiz-deSouza V, Gontijo CM. Covalent coupling of palmitate to ovalbumin inhibits and blocks the induction of oral tolerance. Scand J Immunol. 2002; 55:570-576.

Oliveira FM, Silva-Neto AF, Silva CA, Gontijo CM. Coupling of palmitate to ovalbumin inhibits the induction of oral tolerance. Braz J Med Biol Res. 1998; 31:1421-1424.

Onodera T, Jang MH, Guo Z, Yamasaki M, Hirata T, Bai $\mathrm{Z}$ et al. Constitutive expression of IDO by dendritic cells of mesenteric lymph nodes: functional involvement of the CTLA-4/B7 and CCL22/CCR4 interactions. J Immunol. 2009: 183(9): 5608-5614.

Reddy LH, Murthy RS. Lymphatic transport of orally administered drug. Indian J Exp Biol. 2002; 40:10971109.

Sun ZW, Wang XD, Deng XM, Wallén R, Gefors L, Hallberg E, Andersson R. The influence of circulatory and gut luminal challenges on bidirectional intestinal barrier permeability in rats. Scand J Gastroenterol. 1997; 32:995-1004.

Tabata Y, Inoue Y, Ikada Y. Size effect on systemic and mucosal immune responses induced by oral administration of biodegradable microspheres. Vaccine. 1996; 14(17/18):1677-1685.

Titus RG, Chiller JM. Orally induced tolerance: definition at the cellular level. Int Arch Allergy Appl Immun. 1981: 65: 323-338.

Westlund J, Livingston M, Fahlén-Yrlid L, Oldenborg P-A, Yrlid U. CD47-deficient mice have decreased production of intestinal $\operatorname{IgA}$ following oral immunization but maintained capacity to induce oral tolerance. Immunol. 2012. 135(3): 236-244.

Yamamoto M, Rennert P, McGhee JR, Kweon MN, Yamamoto S, Dohi T. Alternate mucosal system: organized Peyer's patches are not required for IgA responses in the gastrointestinal tract. J Immunol. 2000; 164(10):5184-5191.

Zhou L, Chong MM, Littman DR. Plasticity of CD4+ T cell lineage differentiation. Immunity. 2009: 30(5): 646-655. 